\title{
RESPONS LABU MADU (Cucurbita moschata Durch) TERHADAP ZAT PENGATUR TUMBUH ALAMI DENGAN BERBAGAI DOSIS
}

\author{
(Fitri Kurniati ${ }^{*}$ ), Ida Hodiyah $\left.{ }^{* *}\right)$, Tedi Hartoyo**), Indra Nurfalah ${ }^{* \star \star *}$ ) \\ (** Lecturer Agrotechnology Departement, ${ }^{* * *}$ ) Lecturer of agribusiness Departement \\ ,**** Students of Agrotechnology Departement Agriculture Faculty of Siliwangi University) \\ Author Contact: HP 081323660011, E-mail: fitri.kurniati61@gmail.com
}

\begin{abstract}
The purpose of the research was to studied the response of honey pumpkin (Cucurbita moschata Durch) to the kind of natural PGRs substances in various dosages. The research was conducted at the Greenhouse of griculture Faculty Siliwangi University since April 2017 until September 2017, by ecperiment method using Randomized Block Design, 9 treatments, i.e., b0: control, b1: onion bulb $200 \mathrm{ml}$, b2: onion bulb $300 \mathrm{ml}$, b3: bamboo shoots 200 ml, b4: bamboo shoots $300 \mathrm{ml}$, b5: banana $200 \mathrm{ml}$, banana b6: banana $300 \mathrm{ml}$, b7: mix (onion bulb + bamboo shoots + banana) $200 \mathrm{ml}$, b8: mix (onion bulb + bamboo shoots + banana) $300 \mathrm{ml}$. Each of treatmnent replicated three times. The parameters analyzed were plant height, number of leaves, leaf area, plant dry weight, fruit weight per plant, fruits weight per pieces, fruit length, and fruit diameter. The results showed that honey pumpkin gave the same response to the natural PGRs with various dosages on plant height, number of leaves, plant dry weight, fruit weight, fruit length, and fruit diameter. But, honey pumpkin gave the different response on the leaves area and fruit weight per plant. The largest leaves was found by giving extract of banana bulb of $300 \mathrm{ml}\left(7119.8 \mathrm{~cm}^{2}\right)$ and the mixture extract (onion bulb + bamboo shoots + banana bulb) of $300 \mathrm{ml}\left(6978.5 \mathrm{~cm}^{2}\right)$. The highest of fruit weight per plant is in extract of bamboo shoots $300 \mathrm{ml}(388.6 \mathrm{~g})$, and extract of banana bulb $300 \mathrm{ml}(347.6 \mathrm{~g})$.
\end{abstract}

Keywords: Plant Growth Regulators, Butternut Squash, Onion, Bamboo Shoots, Banana

Kurniati F, Hodiyah I, Hartoyo T, Nurfalah I. 2018. Respon labu madu (Cucurbita moschata Durch) terhadap zat pengatur tumbuh alami dengan berbagai dosis. Agrotech Res J 2(1): 16-21.

Kurniati F, Hodiyah I, Hartoyo T, Nurfalah I. 2018. Response of honey pump (Cucurbita moschata Durch) against natural growth regulators with dosage. Agrotech Res J 2(1): 16-21.

\section{PENDAHULUAN}

Labu madu/butternut squash (Cucurbita moschata Durch) memiliki banyak kandungan karbohidrat juga kaya serat, vitamin $A, C$ dan E dan mineral, membantu meningkatkan kekebalan tubuh dan melawan radikal bebas. Warna oranye pada labu mengandung betakaroten tinggi, sebuah antioksidan yang mengubah vitamin A dan membantu mengurangi risiko kanker. Labu madu juga mengandung B-Kompleks vitamin seperti folat, niacin, vitamin B-6 (pyridoxine), thiamin, dan asam pantotenat, dan mineral seperti tembaga, kalsium, besi dan fosfor (Logistik BPPI, 2016).

Di Indonesia yang beriklim tropis, labu madu dapat tumbuh baik asalkan curah hujan mencukupi sepanjang tahun (http: //guruilmuwan blogspot.co.ic/2015/08/cara budidaya-waluh-organik). Peningkatan produktifitas labu madu merupakan tantangan untuk meningkatkan produksi komoditas hortikultura secara umum, pendapatan nasional serta mengurangi komoditas impor. Menurut Pardede (2014) konsumsi labu di Indonesia masih rendah, hanya 2 persen dari konsumsi sayur nasional (40 kg/kapita/tahun). Harga labu madu lebih tinggi daripada labu biasa.

Upaya peningkatan hasil tanaman dilakukan dengan berbagai cara, diantaranya menggunakan zat pengatur tumbuh (zpt). Wareing and Phillips (1981), mengatakan bahwa pada pertumbuhan tanaman, terdapat peranan zpt di samping unsur hara tercukupi, bahkan bila tanpa zpt maka tidak akan terjadi pertumbuhan.

${ }^{*}$ Fak. Pertanian Universitas Siliwangi Jl. Siliwangi No. 24 Kota Tasikmalaya
Tiga dari lima jenis zpt dalam tanaman adalah auksin, giberellin, sitokinin. Dikemukakan Gardner, Pearce dan Mitchell (2008), bahwa zpt bekerja secara sinergi dalam memunculkan suatu respons tanaman. Misalnya penelitian Tjokrowardojo, Rosman dan Pradono (2009), menunjukkan bahwa auksin bekerjasama dengan sitokinin berpengaruh terhadap persentase perkecambahan kamarandah (Croton tiglium L.) Selanjutnya Lindung (2014), mengatakan bahwa sitokinin bersama dengan auksin dan giberellin merangsang pembelahan sel tanaman . ZPT tersebut berpengaruh terhadap tanaman pada konsentrasi yang sangat kecil dan pengaruh tersebut akan berbeda pada tempat dan waktu yang berbeda. Seperti penelitian Saefas, Rosniawaty, dan Maxiselly (2017), pemberian Benzyl Amino Purin 60 ppm, 90 ppm dan 120 ppm memberikan jumlah daun lebih banyak pada stek teh.

Gardner, Pearce dan Mitchell (2008), mengatakan bahwa untuk mengatasi keterbatasan zpt dalam tanaman, perlu ditambahan zpt eksogen baik sintetik maupun alami, sementara itu penggunaan zpt sintetik di masyarakat masih jarang karena jumlah masih terbatas.

Ada berbagai bahan tanaman yang diduga dapat menjadi pengganti zat pengatur tumbuh sintetik dan mudah diperoleh Misalnya ekstrak bawang merah dianggap sebagai sumber auksin, ekstrak rebung bambu sebagai sumber giberellin dan ekstrak bonggol pisang sebagai sumber sitokinin (Lindung, 2014; Marpaung dan Hutabarat, 2015 ; Marfirani, Rahayu dan Ratnasari, 2014).

Hasil penelitian terdahulu menunjukkan pengaruh yang berbeda-beda pada aplikasi dosis dan konsentrasi 
yang berbeda. Menurut Mardaleni dan Sutriana (2014), pemberian ekstrak rebung dan pupuk Hormon Tanaman Unggul terhadap kacang hijau (Vigna radiata L.) menunjukkan hasil bahwa pemberian ekstrak rebung dengan dosis $4,5 \mathrm{ml} / \mathrm{L}$ air berpengaruh baik terhadap tinggi tanaman, umur panen, jumlah polong per tanaman dan dosis $1,5 \mathrm{ml} / \mathrm{L}$ terhadap bobot 100 butir biji. Sementara itu pemberian ekstrak rebung bambu $50 \mathrm{ml} / \mathrm{L}$ tidak berpengaruh terhadap pertumbuhan bibit kelapa sawit (Zulhida dan Rahmadi, 2013). Tetapi penelitian Munar, dkk. (2011), menunjukkan bahwa ekstrak tunas bambu $1 \mathrm{ml} / \mathrm{L}$ efektif untuk tinggi tanaman, jumlah daun, luas daun, berat basah dan kering bibit kelapa sawit (Elaeis guineensis Jacq.). Peneltian Isrianto (2017), menyimpulkan bahwa giberellin organik yang berasal dari rebung bambu memberikan pengaruh pada peningkatan tinggi tanaman, jumlah daun, panjang akar, luas daun, biomassa tanaman keji beling (Strobilanthes crispus L.) konsentrasi $100 \%$.

Penelitian tentang pengaruh jus umbi bawang merah terhadap perkecambahan dan pertumbuhan awal bibit pepaya (Carica papaya L) oleh Ichsanudin (2014), menunjukkan bahwa konsentrasi jus umbi bawang merah $15 \mathrm{ml} / \mathrm{L}$ memberikan hasil tertinggi dibandingkan konsentrasi $5 \mathrm{ml} / \mathrm{L}, 10 \mathrm{ml} / \mathrm{L}$ dan $20 \mathrm{ml} / \mathrm{L}$ pada parameter kecepatan berkecambah, daya kecambah, panjang akar, diameter batang, tinggi bibit, luas daun, berat segar dan berat kering bibit. Sedangkan penelitian Darojat, Resmisari dan Nasichuddin (2015), menunjukkan bahwa ekstrak bawang merah (Allium cepa L) konsentrasi 10\% meningkatkan persen daya kecambah, kecepatan tumbuh, panjang hipocotyl dan panjang akar benih kakao (Theobroma cacao L.)

Penelitian mengenai bonggol pisang telah dilakukan terhadap bunga rosella (Hibiscus sabdarifa L.) yang menunjukkan bahwa produksi bunga rosella paling banyak terdapat pada pada konsentrasi 24\%. Hasil penelitian Kurniati, Sudartini dan Permana (2015), menunjukkan bahwa rebung bambu, bonggol pisang berpengaruh terhadap variabel pertumbuhan yang diamati pada kemiri sunan (Reutealis trisperma (Blanco) Airy Shaw). Pengaruh baik terdapat pada perlakuan konsentrasi rebung bambu, bonggol pisang antara $20 \mathrm{ml} / \mathrm{L}$ sampai $40 \mathrm{ml} / \mathrm{L}$.

Penelitian lainnya oleh Kurniati, Sudartini dan Hidayat (2016), menunjukkan bahwa aplikasi berbagai bahan zpt alami memberikan pengaruh terhadap daya kecambah, tinggi bibit umur 30, 37, 44, 51, dan jumlah daun 51 hst pada kemiri sunan. Aplikasi ekstrak bonggol pisang dicampur air kelapa memberikan hasil paling baik terhadap semua variable. Namun demikian rebung bambu dan bawang merah mempunyai harapan pula untuk diaplikasikan pada benih dan bibit kemiri sunan.

Berdasarkan latar belakang, maka dilakukan percobaan untuk mengetahui respons labu madu Cucurbita moschata Durch terhadap pemberian beberapa jenis bahan zat pengatur tumbuh alami dengan berbagai dosis, sehingga dapat menentukan bahan zpt mana paling tepat beserta dosis.

\section{BAHAN DAN METODE PENELITIAN}

\section{Bahan dan alat Percobaan}

Bahan percobaan yang diperlukan adalah: benih labu (250 butir), polibag berukuran $35 \mathrm{~cm} \times 40 \mathrm{~cm}$ (kapasitas

tanah $10 \mathrm{~kg}$ ), tanah, pupuk kandang, pupuk NPK

bawang merah, rebung bambu, bonggol pisang.

\section{Metode Penelitian}

Penelitian dilakukan pada bulan Mei sampai dengan September 2017 menggunakan Rancangan Acak Kelompok. Perlakuan adalah kombinasi sebagai berikut :

b0(control); b1 (ekstrak bawang merah $200 \mathrm{ml}$ ); b2 (ekstrak bawang merah $300 \mathrm{ml}$ ); b3 (ekstrak rebung bambu $200 \mathrm{ml}$ ); b4 (ekstrak rebung bambu $300 \mathrm{ml}$ ); b5 (ekstrak bonggol pisang $200 \mathrm{ml}$ ); b6 (ekstrak bonggol pisang $300 \mathrm{ml}$ ); b7 (campuran ekstrak bawang merah + rebung bambu + bonggol pisang $200 \mathrm{ml}$ ); b8 (campuran ekstrak bawang merah + rebung bambu + bonggol pisang $300 \mathrm{ml}$ ), diulang tiga kali, sehingga terdapat 27 plot percobaan. Perbedaan respons diuji dengan Uji Fisher pada taraf a 5\%, selanjutnya diuji dengan Uji Duncan (Gomez dan Gomez, 2007).

Pada pelaksanaan, langkah pertama adalah membuat ekstrak dari semua bahan-bahan padat (bawang merah, rebung bambu, bonggol pisang). Bawang merah, rebung bambu dan bonggol pisang, masing-masing diblender. Setiap kg bahan tanaman ditambah satu liter air. Kemudian ditambahkan dekomposer M Bio sebanyak $15 \mathrm{ml}$ per liter air. Bahan tersebut difermentasikan selama 10 hari. Setelah itu bahan-bahan disaring, dan diperoleh ekstrak yang siap digunakan dengan konsentrasi $40 \mathrm{ml} / \mathrm{L}$

Selanjutnya membuat media tanam pada polibag yang terdiri atas campuran tanah dan pupuk kandang. Kemudian merendam benih labu dalam ekstrak zpt selama 12 jam, setelah ditiriskan benih ditanam pada polibag. Pemeliharaan yang dilakukan yaitu pemupukan dengan NPK $5 g$ per polibag. Perlakuan zpt pada bibit mulai bibit berumur satu minggu selanjutnya diberikan setiap minggu.Panen dilakukan setelah tanaman berumur kurang lebih 90 hari setelah tanam.

Pengamatan dilakukan terhadap variabel yang dianalisis statistik, yaitu: tinggi tanaman, jumlah daun, luas daun, bobot buah per tanaman, bobot buah per butir, panjang dan diameter buah. Pengamatan penunjang dilakukan terhadap analisis tanah, jenis hama dan penyakit, temperatur rumah kaca, dan analisis bahan zpt.

\section{HASIL DAN PEMBAHASAN}

\section{Hasil Penelitian}

\section{Tinggi tanaman}

Tinggi tanaman menunjukkan bahwa respon labu madu tidak berbeda terhadap pemberian ekstrak jenis bahan zpt alami berbagai dosis. Tinggi tanaman tidak berbeda nyata pada umur 14, 28, 42 dan 56 hst (Tabel 1). 
Tabel 1 Tinggi labu madu pada ekstrak bahan zpt alami pada umur 14, 28, 42, dan 56 hst

\begin{tabular}{lrrrc}
\hline \multicolumn{1}{c}{ Perlakuan } & \multicolumn{4}{c}{ Tinggi tanaman (hst, cm) } \\
\cline { 2 - 5 } & $14 \mathrm{hst}$ & $28 \mathrm{hst}$ & $42 \mathrm{hst}$ & $56 \mathrm{hst}$ \\
\hline Kontrol & $10,2 \mathrm{a}$ & $122,8 \mathrm{a}$ & $288,7 \mathrm{a}$ & $390,1 \mathrm{a}$ \\
ekstrak umbi bawang merah $200 \mathrm{ml}$ & $10,1 \mathrm{a}$ & $111,3 \mathrm{a}$ & $287,8 \mathrm{a}$ & $382,0 \mathrm{a}$ \\
ekstrak umbi bawang merah $300 \mathrm{ml}$ & $10,7 \mathrm{a}$ & $111,5 \mathrm{a}$ & $286,6 \mathrm{a}$ & $384,6 \mathrm{a}$ \\
ekstrak rebung bambu $200 \mathrm{ml}$ & $10,1 \mathrm{a}$ & $105,0 \mathrm{a}$ & $297,9 \mathrm{a}$ & $396,1 \mathrm{a}$ \\
ekstrak rebung bambu $300 \mathrm{ml}$ & $9,9 \mathrm{a}$ & $119,1 \mathrm{a}$ & $290,9 \mathrm{a}$ & $409,8 \mathrm{a}$ \\
ekstrak bonggol pisang $200 \mathrm{ml}$ & $10,2 \mathrm{a}$ & $113,7 \mathrm{a}$ & $289,8 \mathrm{a}$ & $401,1 \mathrm{a}$ \\
ekstrak bonggol pisang $300 \mathrm{ml}$ & $10,0 \mathrm{a}$ & $125,9 \mathrm{a}$ & $297,3 \mathrm{a}$ & $422,8 \mathrm{a}$ \\
ekstrak campuran (bawang merah + rebung & $9,4 \mathrm{a}$ & $109,1 \mathrm{a}$ & $283,1 \mathrm{a}$ & $389,8 \mathrm{a}$ \\
bambu + bonggol pisang) $200 \mathrm{ml}$ & & & & \\
ekstrak campuran (bawang merah + rebung & $10,7 \mathrm{a}$ & $109,6 \mathrm{a}$ & $298,2 \mathrm{a}$ & $368,4 \mathrm{a}$
\end{tabular}

bambu + bonggol pisang) $300 \mathrm{ml}$

Keterangan: angka rata-rata yang diikuti dengan huruf sama pada satu kolom menunjukkan tidak berbeda berdasarkan uji jarak berganda Duncan a $5 \%$

\section{Jumlah daun}

Jumlah daun labu madu pada umur 14, 28, 42 dan 56 hst, menunjukkan bahwa respon labu madu tidak berbeda terhadap pemberian ekstrak bahan zpt alami. Jumlah daun tidak berbeda nyata pada umur 14, 28, 42, dan 56 hst (Tabel 2).

Tabel 2 Jumlah daun labu madu pada ekstrak bahan zpt alami berbagai dosis pada umur 14, 28, 42 dan 56 hst

\begin{tabular}{lcccc}
\hline \multicolumn{1}{c}{ Perlakuan } & \multicolumn{3}{c}{ Jumlah daun (helai) } \\
\cline { 2 - 4 } & $14 \mathrm{hst}$ & $28 \mathrm{hst}$ & $42 \mathrm{hst}$ & $56 \mathrm{hst}$ \\
\hline Kontrol & $5,0 \mathrm{a}$ & $12,5 \mathrm{a}$ & $24,6 \mathrm{a}$ & $31,0 \mathrm{a}$ \\
ekstrak umbi bawang merah $200 \mathrm{ml}$ & $5,0 \mathrm{a}$ & $12,3 \mathrm{a}$ & $24,4 \mathrm{a}$ & $27,0 \mathrm{a}$ \\
ekstrak umbi bawang merah $300 \mathrm{ml}$ & $4,9 \mathrm{a}$ & $12,0 \mathrm{a}$ & $24,9 \mathrm{a}$ & $30,7 \mathrm{a}$ \\
ekstrak rebung bambu $200 \mathrm{ml}$ & $4,9 \mathrm{a}$ & $11,5 \mathrm{a}$ & $22,9 \mathrm{a}$ & $27,3 \mathrm{a}$ \\
ekstrak rebung bambu $300 \mathrm{ml}$ & $5,0 \mathrm{a}$ & $12,5 \mathrm{a}$ & $23,9 \mathrm{a}$ & $31,7 \mathrm{a}$ \\
ekstrak bonggol pisang $200 \mathrm{ml}$ & $5,0 \mathrm{a}$ & $12,4 \mathrm{a}$ & $24,0 \mathrm{a}$ & $30,3 \mathrm{a}$ \\
ekstrak bonggol pisang $300 \mathrm{ml}$ & $5,0 \mathrm{a}$ & $12,6 \mathrm{a}$ & $24,1 \mathrm{a}$ & $35,0 \mathrm{a}$ \\
ekstrak campuran (bawang merah + rebung bambu & $5,0 \mathrm{a}$ & $12,3 \mathrm{a}$ & $24,2 \mathrm{a}$ & $26,0 \mathrm{a}$ \\
+ bonggol pisang) 200 ml & & & & \\
ekstrak campuran (bawang merah + rebung bambu & $5,0 \mathrm{a}$ & $11,7 \mathrm{a}$ & $23,0 \mathrm{a}$ & $31,7 \mathrm{a}$ \\
+ bonggol pisang) 300 ml & &
\end{tabular}

Keterangan: angka rata-rata yang diikuti dengan huruf sama pada satu kolom menunjukkan tidak berbeda berdasarkan uji jarak berganda Duncan a $5 \%$

\section{Luas daun dan bobot kering tanaman}

Analisis statistik terhadap luas daun labu madu umur 56 hst, menunjukkan bahwa respon labu madu berbeda terhadap pemberian ekstrak bahan zpt alami berbagai dosis. Sementara bobot kering tanaman pada umur 56 hst menunjukkan respons yang tidak berbeda (Tabel 3).

Tabel 3 Luas daun dan bobot kering tanaman labu madu pada umur 56 hst pada ekstrak bahan zpt alami berbagai dosis.

\begin{tabular}{lcc}
\hline \multicolumn{1}{c}{ Perlakuan } & Luas daun $\left(\mathrm{cm}^{2}\right)$ & Bobot kering tanaman $(\mathrm{g})$ \\
\hline Kontrol & $6020,9 \mathrm{~b}$ & $31,8 \mathrm{a}$ \\
ekstrak umbi bawang merah $200 \mathrm{ml}$ & $4755,4 \mathrm{e}$ & $23,4 \mathrm{a}$ \\
ekstrak umbi bawang merah $300 \mathrm{ml}$ & $4944,1 \mathrm{de}$ & $29,7 \mathrm{a}$ \\
ekstrak rebung bambu $200 \mathrm{ml}$ & $6379,1 \mathrm{~b}$ & $27,4 \mathrm{a}$ \\
ekstrak rebung bambu $300 \mathrm{ml}$ & $6109,1 \mathrm{~b}$ & $32,9 \mathrm{a}$ \\
ekstrak bonggol pisang $200 \mathrm{ml}$ & $5527,1 \mathrm{c}$ & $29,8 \mathrm{a}$ \\
ekstrak bonggol pisang $300 \mathrm{ml}$ & $7119,8 \mathrm{a}$ & $38,3 \mathrm{a}$ \\
ekstrak campuran (bawang merah + rebung bambu + & $5331,1 \mathrm{~cd}$ & $28,6 \mathrm{a}$ \\
bonggol pisang) 200 ml & & $32,5 \mathrm{a}$ \\
ekstrak campuran (bawang merah + rebung bambu + & $6978,5 \mathrm{a}$ & \\
bonggol pisang) 300 ml & &
\end{tabular}

Keterangan: angka rata-rata yang diikuti dengan huruf sama pada satu kolom menunjukkan tidak berbeda berdasarkan uji jarak berganda Duncan a $5 \%$ 
Bobot buah per tanaman, bobot buah per butir, panjang buah, dan diameter buah

Analisis statistik terhadap bobot buah per tanaman menunjukkan bahwa respon labu madu berbeda terhadap pemberian ekstrak bahan zpt alami berbagai dosis, sedangkan terhadap bobot buah per butir, panjang buah dan diameter buah tidak berbeda (Tabel 4).

Tabel 4 Bobot buah per tanaman dan per butir, panjang dan diameter buah pada ekstrak bahan zpt alami

\begin{tabular}{|c|c|c|c|c|}
\hline Perlakuan & $\begin{array}{l}\text { Bobot buah per } \\
\tan (\mathrm{g})\end{array}$ & $\begin{array}{l}\text { Bobot buah } \\
\text { per butir }(\mathrm{g})\end{array}$ & $\begin{array}{l}\text { Panjang } \\
\text { buah }(\mathrm{cm})\end{array}$ & $\begin{array}{l}\text { Diameter } \\
\text { buah }(\mathrm{cm})\end{array}$ \\
\hline Kontrol & $261,6 \mathrm{~cd}$ & $261,6 \mathrm{a}$ & $12,6 \mathrm{a}$ & $11,9 \mathrm{a}$ \\
\hline ekstrak umbi bawang merah 200 ml & $263,9 \mathrm{c}$ & 263,9 a & $12,7 \mathrm{a}$ & $11,4 \mathrm{a}$ \\
\hline ekstrak umbi bawang merah $300 \mathrm{ml}$ & 230,3 de & $230,3 \mathrm{a}$ & $11,6 \mathrm{a}$ & $11,0 \mathrm{a}$ \\
\hline ekstrak rebung bambu 200 ml & $308,3 \mathrm{~b}$ & 243,9 a & $11,8 \mathrm{a}$ & $11,2 \mathrm{a}$ \\
\hline ekstrak rebung bambu $300 \mathrm{ml}$ & 388,6 a & $340,7 \mathrm{a}$ & $13,4 \mathrm{a}$ & $12,8 \mathrm{a}$ \\
\hline ekstrak bonggol pisang $200 \mathrm{ml}$ & $268,0 \mathrm{c}$ & 228,6 a & $12.3 \mathrm{a}$ & $11,1 \mathrm{a}$ \\
\hline ekstrak bonggol pisang $300 \mathrm{ml}$ & $347,6 \mathrm{ab}$ & 347,6 a & $13,8 \mathrm{a}$ & $12,9 \mathrm{a}$ \\
\hline $\begin{array}{l}\text { ekstrak campuran (bawang merah + rebung } \\
\text { bambu + bonggol pisang) } 200 \mathrm{ml}\end{array}$ & $232,7 \mathrm{~d}$ & $232,7 \mathrm{a}$ & $11,7 \mathrm{a}$ & $10,9 \mathrm{a}$ \\
\hline $\begin{array}{l}\text { ekstrak campuran (bawang merah + rebung } \\
\text { bambu + bonggol pisang) } 300 \mathrm{ml}\end{array}$ & $210,5 \mathrm{e}$ & $210,5 \mathrm{a}$ & $11,5 \mathrm{a}$ & $10,1 \mathrm{a}$ \\
\hline
\end{tabular}

Keterangan : angka rata-rata yang diikuti dengan huruf sama pada satu kolom menunjukkan tidak berbeda berdasarkan uji jarak berganda Duncan a $5 \%$

\section{Pembahasan}

Komponen pertumbuhan yaitu tinggi tanaman, jumlah daun, dan bobot kering tanaman menunjukkan bahwarespons yang tidak berbeda terhadap pemberian ekstrak jenis bahan zpt alami berbagai dosis. Berbagai faktor memungkinkan terjadi kondisi tersebut. Seperti dikatakan Salisbury dan Ross (1995). bahwa zpt mempengaruhi proses fisiologis sehingga terdapat respons pada berbagai bagian tumbuhan. Respons bergantung pada spesies, bagian tumbuhan, fase perkembangan, konsentrasi zpt, interaksi antara jenis zpt, dan faktor lingkungan. Tinggi tanaman, jumlah daun dan bobot kering tanaman memberikan respons yang sama karena faktor lingkungan, yaitu suhu cukup tinggi, karena penelitian dilakukan di rumah kaca. Interaksi antara bagian tumbuhan dengan suhu inilah yang menjadi penyebab tinggi tanaman, jumlah daun dan bobot kering memberikan respons sama terhadap pemberian ekstrak jenis bahan zpt alami berbagai dosis.

Menurut Harjadi (1986), jumlah daun berkaitan dengan tinggi tanaman, semakin tinggi tanaman maka semakin banyak daun yang terbentuk karena daun terbentuk pada nodus-nodus tempat kedudukan daun pada batang. Pada penelitian tinggi tanaman menunjukkan respons yang tidak berbeda terhadap pemberian ekstrak jenis bahan zpt alami berbagai dosis, sehingga jumlah daunpun menjadi tidak berbeda pula. Selanjutnya dikatakan Gardner et al (2008), bahwa jumlah dan ukuran daun dipengaruhi oleh faktor genotip dan lingkungan.

Pada komponen luas daun, menunjukkan bahwa labu madu memberikan respons berbeda terhadap pemberian ekstrak bahan zpt alami berbagai dosis. Luas daun terbesar terdapat pada pemberian ekstrak bahan zpt bonggol pisang dengan dosis $300 \mathrm{ml}$ dan tidak berbeda dengan pemberian ekstrak campuran bawang merah, rebung bambu dan bonggol pisang dengan dosis 300 ml.Berdasarkan hasil analisis bahan zpt menunjukkan bahwa pada bonggol pisang terdapat sitokinin dalam bentuk kinetin yang lebih tinggi daripada bawang merah dan rebung bambu. Selain sitokinin juga terdapat auksin dan gibberellin (Idonesian Center For Biodiversity And Biotechnology (2016). Maspary (2012) dan Lindung (2014) juga mengatakan, bahwa untuk membuat zpt alami sitokinin adalah bonggol pisang. Selain itu penelitian Rostikawati (2015), menunjukkan bahwa jumlah bunga rosella (Hibiscus sabdariffa L), dipengaruhi oleh konsentrasi MOL bonggol pisang. Produksi bunga terbaik terdapat pada konsentrasi 24 persen.

Seperti dikatakan Wareing dan Phillips (1981), bahwa sitokinin mampu meningkatkan pertumbuhan dengan pembelahan sel, merangsang pembentukan tunas pada batang, dan mempercepat pertumbuhan memanjang. Gardner et al (1991), juga mengatakan bahwa sitokinin merupakan zat yang dapat merangsang sitokinesis (pembelahan sel). Kinin menimbulkan respons dengan kisaran luas dan bertindak sinergis dengan hormon lainnya. Peranan lain adalah dalam penyimpanan klorofil, pengumpulan asam amino, dan penyimpanan protein dalam daun (Quinland dan Weaver, 1969 dalam Gardner et al, 2008).

Penelitian Ratnawati, Saputra dan Yoseva (2013), sitokinin yang terdapat pada air kelapa juga memperlihatkan pengaruh yang baik terhadap tinggi bibit dan luas daun kakao.

Respon labu madu berbeda terhadap pemberian bahan zpt alami yang ditunjukkan oleh perbedaan bobot buah per tanaman. Bobot buah terbesar terdapat pada perlakuan rebung bambu $300 \mathrm{ml}$ dan tidak berbeda dengan bahan zpt bonggol pisang $300 \mathrm{ml}$. Pada rebung bambu terdapat zpt giberellin seperti yang nampak pada hasil analisis bahan zpt. Giberellin merupakan zat pengatur tumbuh yang mampu meningkatkan jumlah dan ukuran sel, Seperti dikemukakan Salisbury dan Ross (1995), bahwa zat itu meningkatkan hidrolisis pati, fruktan dan selulosa menjadi molekul glukosa dan fruktosa. Selanjutnya gula tersebut menyediakan energy melalui respirasi, berperan dalam pembentukan dinding sel, dan juga 
membuat potensial air lebih negatif pada saat tertentu. Akibatnya air bergerak masuk lebih cepat yang menyebabkan pemelaran dan pengenceran gula. Sebenarnya bukan hanya pemanjangan batang yang terpacu oleh giberellin tapi juga seluruh pertumbuhan termasuk daun dan akar. Dikatakan oleh Djamal (2012), bahwa pertumbuhan tanaman ditentukan oleh unsur hara, sementara arah dan kualitas dari pertumbuhan dan perkembangan sangat ditentukan oleh zat pengatur tumbuh. Pemberian zpt yang tepat baik komposisinya maupun konsentrasinya dapat mengarahkan pertumbuhan dan perkembangan tanaman. Juga dikatakan oleh Lindung (2014), bahwa peranan giberellin bagi tanaman adalah mendorong sintesis enzim dalam biji, berperan dalam pemanjangan sel, dan meningkatkan pembungaan. Lebih dulu dikemukakan juga oleh Salisbury dan Ross (1995), bahwa giberellin jauh lebih efektif dalam mendorong pembungaan daripada faktor lain.Penelitian serupa oleh Mardaleni dan Sutriana (2014) menunjukkan bahwa pemberian ekstrak rebung $4,5 \mathrm{ml} / \mathrm{L}$ air memberikan pengaruh baik terhadap tinggi, dan bobot polong kacang kacang hijau. Seperti dikatakan oleh Salisbury dan Ross (1995), bahwa giberellin lebih efektif dalam mendorong pembungaan daripada faktor lain.

Ekstrak bonggol pisang $300 \mathrm{ml}$ menghasilkan bobot buah per tanaman yang tidak berbeda dengan rebung bambu $300 \mathrm{ml}$. Pada bonggol pisang terdapat sitokinin yang relatif lebih tinggi dibandingkan dengan bahan lainnya. Dikemukakan oleh Maspary (2012), bahwa bonggol pisang mengandung giberellin dan sitokinin.Fungsi sitokinin menurut Skoog dalam Salisbury dan Ross (1995), adalah memacu pembelahan sel dan pembentukan organ. Sitokinin juga dapat meningkatkan wadah penampung unsur hara, berupa jaringan yang muda. Selain daun yang muda diketahui bahwa bunga dan buah merupakan limbung (penampung) unsure hara yang besar. Maka dengan pemberian sitokinin, dihasilkan buah lebih berat dibandingkan dengan pemberian bahan zpt lainnya.

Dukungan komponen pertumbuhan juga terlihat pada komponen luas daun yang menunjukkan bahwa ekstrak bonggol pisang memberikan luas daun terbesar, berdampak pada bobot buah per tanaman juga cukup besar dibandingkan dengan yang lain kecuali rebung bambu $300 \mathrm{ml}$. Pada rebung bambu walaupun luas daun tidak menunjukkan paling besar tetapi mampu memberikan bobot buah paling tinggi karena lebih efisien mempergunakan fotosintat yang dihasilkan. Efisiensi penggunaan fotosintat salah satunya dipengaruhi posisi daun. Daun yang mengarah pada sinar matahari dan tidak saling menutupi akan lebih efisien dan banyak menyimpan cadangan makanan pada buah.

Bobot buah per butir, panjang buah, dan diameter buah tidak menunjukkan perbedaan, Menurut Salisbury dan Ross (1995), zat pengatur tumbuh adalah senyawa organik yang disintesis di salah satu bagian tumbuhan, dipindahkan ke bagian lain dan pada konsentrasi sangat rendah mampu menimbulkan respons fisiologis. Respons itu bergantung pada spesies, bagian tumbuhan, fase perkembangan, konsentrasi hormon, interaksi antar hormon yang diketahui, dan berbagai faktor lingkungan. Artinya respons zpt itu sangat dipengaruhi oleh lingkungan. Selain itu, sama halnya dengan pupuk, zpt akan memberikan pengaruh yang berbeda tergantung kepada jenis, konsentrasi, dosis, waktu, dan tempat pemberian.

\section{Kesimpulan dan Saran}

Berdasarkan percobaan dan pengolahan data yang dilakukan, dapat disimpulkan bahwa :

1. Labu madu memberikan respons yang sama terhadap semua perlakuan ekstrak bahan zpt alami berbagai dosis pada parameter tinggi tanaman, jumlah daun, bobot kering tanaman, bobot buah per butir, panjang buah, dan diameter buah.

2. Labu madu memberikan respons berbeda pada parameter luas daun dan bobot buah per tanaman. Luas daun terbesar terdapat pada pemberian ekstrak bonggol pisang $300 \mathrm{ml}\left(7,119,77 \mathrm{~cm}^{2}\right)$ dan campuran (bawang merah + rebung bambu + bonggol pisang) $300 \mathrm{ml}\left(6978,5 \mathrm{~cm}^{2}\right)$. Bobot buah terbesar terdapat pada rebung bambu $300 \mathrm{ml}$ $(388,6 \mathrm{~g})$ dan bonggol pisang $300 \mathrm{ml}(347,6 \mathrm{~g})$. berikut :

Selanjutnya dapat disarankan hal-hal sebagai

1. Dalam pembudidayaan labu madu dapat digunakan zat pengatur tumbuh alami ekstraki bonggol pisang atau rebung bambu dengan konsentrasi $40 \mathrm{ml} / \mathrm{L}$ dan dosis $300 \mathrm{ml}$.

2. Dapat ditelaah lebih lanjut tentang dosis dan konsentrasi bahan zat pengatur tumbuh alami, dan juga penerapan pada komoditas yang lain

\section{DAFTAR PUSTAKA}

Anonim. 2014. Cara membuat zat pengatur tumbuh alami.http://kebun-hydroponik.blogspot.com/2014/07 /cara-membuat-zat-pengatur-tumbuh-alami.html.

Anonim. 2015. Cara budidaya waluh organik dari biji agarberbuah lebat danmenguntungkan petani. http: //guruilmuwanblogspot.co.id/ 2015/08/vara budidaya - waluh-organik.

Darojat MK, RS. Resmisari, Ach Nasichuddin. 2015 Pengaruh konsentrasi dan lama perendaman ekstrak bawang merah (Allium cepa L.) terhadap viabilitas benih kakao (Theobroma cacao L.). Universitas Islam Negeri Maulana Malik Ibrahim Malang.http://etheses.uin-malang.ac.id/ 37/12/106200 12\%20Ringkasan.pdf

Djamal A. 2012. Pembuatan produk hormon tumbuhan komersial dan pemanfaatan hormon untuk berbagai tujuan. http:www.jasakonsultan. com/pembuatanproduk-hormon-tumbuhan-komersial-dan pemanfaatan-hormon-untuk-berbagai tujuan.

Frank B, Salisbury and Cleon W. Ross. 1995. Plant physiology. Penerjemah Diah Lukman dan Sumar yono. Fisiologi Tumbuhan Jilid 3. Perkembangan Tumbuhan dan Fisiologi Lingkungan. Edisi 4. Penerbit ITB. Bandung 
Franklin P, Gardner, R.Brent. Pearce, Roger L. Mitchel. 2008. Fisiologi of Plant. Terjemahan Herawati Susilo dan Subiyanto. Fisiologi tanaman Budidaya. Universitas Indonesia Press. Jakarta.

Harjadi SS. 1991. Pengantar agronomi. Penerbit PT. Gramedia Pustaka Utama. Jakarta.

Ichsanudin FN. 2014. Pengaruh konsentrasi jus umbi bawang merah terhadap perkecambahan dan pertumbuhan awal bibit Carica papaya. UNS Digital Library.

Isrianto PL. 2017. Pengaruh giberellin organik terhadap pertumbuhan tanaman keji beling (Strobilanthes crispus). Jurnal Biologi dan Pembelajaran Biologi. 2 (1): 23-37.

Kurniati F, Tini Sudartini, Diki Permana. 2015. Pengaruh konsentrasi berbagai jenis bahan zat pengatur tumbuh alami terhadap pertumbuhan bibit kemiri sunan (Reutealis trisperma) (Blanco) Airy Shaw). Laporan Penelitian Hibah Bersaing. LP2MPMP UNSIL

Kurniati F, Tini Sudartini, Dikdik Hidayat. 2017. Aplication of various natural pgrs to increase the growth of candlenut (Reutealis trisperma) CV. Sunan. Jurnal Agro. 4(1): 40-49.

Kwanchai A, Gomez, Arturo A, Gomez. 2007.Prosedur statistik untuk penelitian pertanian. Penerjemah Endang Sjamsudin, Justika S. Baharsjah. UI-Press. Jakarta.

Lindung. 2014. Teknologi aplikasi zat pengatur tumbuh. Jambi: Balai Pelatihan Pertanian.

Logistik Bimbingan Pupuk Dan Pemupukan Indonesia. 2016. Acuan pupuk dan pemupukan labu madu/butternutsquash. http://booslem.com/ budi daya-butternut-labu-madu/. Diunduh November 2016.

Mardaleni, Sutriana S. 2014. Pemberian ekstrak rebung dan pupuk hormon tanaman unggul terhadap pertumbuhan dan produksi kacang hijau (Vigna radiata L). Jurnal Dinamika Pertanian. 29 (1): 2014.

Marfirani M, Yuni Sri Rahayu, Evie Ratnasari. 2014. Pengaruh berbagai konsentrasi filtrat umbi bawang merah dan rootone $f$ terhadap pertumbuhan stek melati "Rato Ebu. Universitas Negeri Surabaya. Lentera Bio. 3 (1): 73-76.

Marpaung AE, Hutabarat RC. 2015. Respons jenis perangsang tumbuh berbahan alami dan asal stek batang terhadap pertumbuhan bibittin (Ficus carica L.) Jurnal Hortikultura. 25(1) : 37-43.

Maspary. 2012. Apa kehebatan MOL bonggol pisang.Gerbang Pertanian. Wajah pertanian Indonesia.http://www.gerbangpertanian.com/2012/0 5/apa-kehebatan-mol-bonggol-pisang.html

Munar A, Azharuddin Lubis, Abdullah Yaksan, Ade Ryantika, Khairunnas, Juwita Tarigan. 2011. Kajian ekstrak tunas bambu dan tauge terhadap pertumbuhan tanaman kelapa sawit (Elaeis guineensis Jack) pada pembibitan pre nursery. Volume 16 No 3 : 153-157
Pardede G. 2014. Labu berpotensi menjadi pengganti beras. yayasan bina tani sejahtera. http://www.pikiran-rakyat.com/horison/2014/10/08/ 00064/labu-berpotensi-menjadi-pengganti-beras. Diunduh Desember 2017.

Zulhida R, Windi Rahmadi. 2013. Ekstrak tunas bambu (rebung) dan kompos meningkat kan pertumbuhan bibit kelapa sawit (Elaeis guineensis Jacq) L.) di Main Nursery. Agrium. 18 (1): 32-36.

Ratnawati, Sukemi Indra Saputra, Sri Yoseva. 2013. Waktu perendaman benih dengan air kelapa muda terhadap pertumbuhan bibit kakao (Theobroma cacao L.). Universitas Riau. http://download.portal garuda.org/article. ptip\%

Rostikawati T. 2015. Pengaruh pemberian mikroorganisme local (MOL) bonggol pisang nangka terhadap produksi rosella (Hibiscus sabdariffa L). https://www.academia.edu/signup?a_id=34911218. Diunduh 11 November 2015.

Saefas SA, S Rosniawaty, Y Maxiselly. 2017. Pengaruh konsentrasi zat pengatur tumbuh alami dan sintetik terhadap pertumbuhan tanaman teh (Camelia sinensis (L.) O. Kuntze) klon GMB 7 setelah centering. Jurnal Kultivasi.16 (2): 368-372.

Tjokrowardojo, A.S., Rosihan Rosman, dan Dyah Iswantini Pradono. 2009. Pengaruh zat pengatur tumbuh terhadap perkecambahan benih dan pertumbuhan bibit kamarandah (Croto tiglium L.). Jurnal Agrotropika. 14(2): 55-60.

Wareing PF, I.D.J. Phillips. 1981. The control of growth and differentiation in plants. Pergamon Press. New York. 